\title{
Isolation and Identification of Nuc Nuclease Gene and Sea Enterotoxin Gene in Staphylococcus Aureus Isolates From Nasal Mucosa of Burn Hospital Staff
}

\section{Roxana Karimzadeh}

Islamic azad university Ayatollah Amoli Branch

Romina Karimzadeh Ghassab ( $\square$ romina.karimzadeh@gmail.com )

Department of Clinical Biochemistry, Iran University of Medical Sciences, Tehran, Iran

\section{Research note}

Keywords: Staphylococcus aureus, nuc Nuclease Gene, sea Enterotoxin, PCR

Posted Date: August 27th, 2020

DOI: https://doi.org/10.21203/rs.3.rs-64816/v1

License: (a) (1) This work is licensed under a Creative Commons Attribution 4.0 International License. Read Full License 


\section{Abstract}

Objectives: Staphylococcus aureus is one of the main causes of nosocomial infections. The hospital staff as carriers of Staphylococcus aureus have an important role in spreading it among patients. This study aimed to investigate nuc gene, as $S$. aureus marker and sea gene, enterotoxin A gene nasal mucosa of sari burn hospital staff. In this cross-sectional study, a nasal swab of 40 staff of Burnt hospital of Sari was collected and isolated. The $S$. aureus was detected by biochemical tests such as Gram stain, catalase, coagulase. Then nuc and sea genes were identified after the extraction of DNA, by PCR technique and gel electrophoresis with specific primer.

Results: From the 40 strains obtained from nasal of carriers, $20 \mathrm{~S}$. aureus strains were isolated, and all of them included nuc gene, while 6 samples included sea gene. Given that every 20 samples had nuc gene, therefore this gene is a strong marker for $S$. aureus. Also, the presence of sea genes in some samples suggested the presence of enterotoxin A in hospital staff as a healthy carrier. Also, given that hospital staffs can be carriers of Staphylococcus aureus and spreading nosocomial infections, therefore identification of the carriers to prevent the spread of infection is essential.

\section{Introduction}

Staphylococcus aureus is an opportunistic pathogen that produces numerous exotoxins and is the most common cause of infection in hospitals after Pseudomonas aeruginosa [1]. Various studies show that $15-80 \%$ of Staphylococcus aureus strains isolated from different sources can produce enterotoxin [1-3]. Among staphylococcal enterotoxins, sea (enterotoxin A) type is more resistant to heat and gastrointestinal proteolytic enzymes such as pepsin and trypsin [4].

The nuc gene acts as a marker and also the presence of heat resistant nuclease gene (nuc) is strongly associated with the production of enterotoxin and it can be considered as an indicator of infection with enterotoxin producer Staphylococcus aureus [5].

There are several methods for detecting toxins in this bacterium, including latex agglutination, ELISA immunochromatography, and latex immunoassay, and magnetic immunoassay. In all these methods, it is necessary to provide conditions for the expression of the staphylococcal enterotoxin gene to identify these toxins. Molecular detection methods are also used to identify staphylococcal enterotoxin genes that not only do not require these conditions but are also able to identify staphylococci that have secreted low levels of the toxin, which cannot be detected by immunological methods [6]. PCR can detect the susceptibility of enterotoxin-producing strains, especially when enterotoxin genes are not expressed due to different conditions. In these cases, it is important to search for Staphylococcus aureus strains containing the classic enterotoxin genes SEA-SEE; Because these enterotoxins in very small amounts can also cause severe food poisoning. For this reason, many researchers today use this method to identify strains of Staphylococcus aureus that produce enterotoxins [7]. 
Nosocomial infections are secondary infections that a patient acquires during hospitalization. One of the most common bacteria causing nosocomial infections is Staphylococcus aureus, which due to various virulence factors can play an important role in the transmission of seemingly healthy carriers to patients in various departments, including burns and intensive care units [8]. Due to the importance of Staphylococcus aureus strains in nosocomial infections and the role of enterotoxins as superantigens in various diseases, the present study aimed to isolate and identify the sea and nuc genes that encoding enterotoxin in Staphylococcus aureus isolates, isolated from Nasal mucosa of staff in Sari burn hospital by PCR method.

\section{Main Text}

\section{Methods}

In this descriptive cross-sectional study 40 samples were collected from the nasal mucosa of Sari burn hospital staff and cultured on the nutrient agar medium (Merck, Germany). In the next step, colonies suspected of Staphylococcus aureus were tested using gram staining, catalase, oxidase, and coagulase tests. Colonies suspected of Staphylococcus aureus were cultured in mannitol salt agar medium (Merck, Germany). After culturing the bacteria in the mannitol salt agar medium, after 24 hours of culturing the bacteria, a colony loop was inoculated into the nutrient broth medium (Merck, Germany). After 24 hours' incubation at $37^{\circ} \mathrm{C}$, glycerol was added to the mixture of bacteria and broth medium in a ratio of 70 to 30. The resulting suspension was transferred to the Eppendorf and stored at $-80^{\circ} \mathrm{C}$.

\section{DNA extraction}

DNA extraction was done by DNA extraction Kit (CinnaGene Co., Iran). $1.5 \mathrm{ml}$ of microbial suspensions were centrifuged at $4500 \mathrm{rpm}$ for 4 minutes. $100 \mu \mathrm{l}$ of the precipitant was mixed with $400 \mu \mathrm{l}$ of the lysis solution and vortexed for 15 to 20 seconds. In the next step, $300 \mu$ of the precipitating solution was added to the mixture and mixed for 3 to 5 seconds and placed at $20^{\circ} \mathrm{C}$ for 20 minutes. It was then centrifuged at $12,000 \mathrm{rpm}$ for 10 minutes and gently emptied by inverting the tube and placing it on paper for 2 to 3 seconds. One $\mathrm{ml}$ of wash buffer was added to the resulting precipitate and vortexed for 3-5 seconds. It was centrifuged at 12,000 rpm for 5 minutes, then the wash buffer was completely evacuated and placed at $65^{\circ} \mathrm{C}$ for 5 minutes to dry. The precipitate was completely dissolved in $30 \mu \mathrm{l}$ of the solvent buffer by gentle shaking and placing at $65^{\circ} \mathrm{C}$ for $5 \mathrm{~min}$. The insoluble material was centrifuged at 12,000 RPM 30 seconds. The supernatant contains pure DNA.

\section{Identification of sea and nuc nuclease genes by PCR}

In the PCR of the sea and nuc nuclease genes, their specific primers were used after blasting in NCBI to ensure their specificity. These primers were provided by Pishgam Company, Iran. Table 1 lists the specifications for the primers used. The amount and volume of materials required for the PCR and temperature program of the Thermal cycler device (BIO-RAD, USA) are mentioned in Table 2. 
Table 1

The specifications for the primers

\begin{tabular}{|lll|}
\hline Name & Sequence $\mathbf{( 5 - 3 )}$ & Amplitude size \\
\hline Nuc F & GCGATTGATGGTGATACGGTT & 279 \\
Nuc R & AGCCAAGCCTTGACGAACTAAAGC & 279 \\
Sea F & GGAGTTGGATCTTCAAGCAAGAC & 86 \\
Sea R & CCCTCTGAACCTTCCCATCAAA & 86 \\
Staphylococcus aureus F & AGTTTGATCCTGGCTC & 500 \\
Staphylococcus aureus R & CCTACGTATTACCGCGGC & 500 \\
\hline
\end{tabular}


Table 2

Thermal cycling device temperature program, and the amount and concentration of materials required for PCR

\begin{tabular}{|c|c|c|c|c|c|}
\hline Cycles & Steps & Temperature & Time & Materials & \\
\hline \multicolumn{4}{|c|}{ Staphylococcus aureus } & Materials & Amounts \\
\hline First step: 1 cycle & Denaturation & 94 & $4 \mathrm{~min}$ & $10 \mathrm{X}$ buffer solution & $2.5 \mathrm{ml}$ \\
\hline \multirow{3}{*}{$\begin{array}{l}\text { Second step: } 35 \\
\text { cycles }\end{array}$} & Denaturation & 95 & $45 \mathrm{sec}$ & \multirow[t]{3}{*}{ NTPs (10 mM) } & \multirow[t]{3}{*}{$0.5 \mathrm{ml}$} \\
\hline & Annealing & 57 & $1 \mathrm{~min}$ & & \\
\hline & Extension & 72 & $1 \mathrm{~min}$ & & \\
\hline Third step: 1 cycle & Extension & 72 & $10 \min$ & $\begin{array}{l}\text { Magnesium chloride } \\
(50 \mathrm{mM})\end{array}$ & $0.75 \mathrm{ml}$ \\
\hline sea gene & & & & Forward primer & 1 \\
\hline First step: 1 cycle & Denaturation & 95 & $5 \mathrm{~min}$ & Reverse Primer & 1 \\
\hline \multirow{3}{*}{$\begin{array}{l}\text { Second step: } 35 \\
\text { cycles }\end{array}$} & Denaturation & 94 & $50 \mathrm{sec}$ & \multirow[t]{3}{*}{ Template } & \multirow[t]{3}{*}{5} \\
\hline & Annealing & 59.5 & $40 \mathrm{sec}$ & & \\
\hline & Extension & 72 & $50 \mathrm{sec}$ & & \\
\hline Third step: 1 cycle & Extension & 72 & $5 \mathrm{~min}$ & DNA polymerase & $0.2 \mathrm{ml}$ \\
\hline nuc gene & & & & Double-distilled water & $14.05 \mathrm{ml}$ \\
\hline First step: 1 cycle & Denaturation & 95 & $5 \mathrm{~min}$ & Total volume & $25 \mathrm{ml}$ \\
\hline \multirow{3}{*}{$\begin{array}{l}\text { Second step: } 37 \\
\text { cycles }\end{array}$} & Denaturation & 94 & $1 \mathrm{~min}$ & & \\
\hline & Annealing & 55 & $40 \mathrm{sec}$ & & \\
\hline & Extension & 72 & $1.5 \mathrm{~min}$ & & \\
\hline Third step: 1 cycle & Extension & 72 & $1 \mathrm{~min}$ & & \\
\hline
\end{tabular}

\section{Electrophoresis of PCR products}

PCR products were electrophoresed using $1 \%$ agarose gel (Merck, Germany). A mixture of $1 \lambda$ DNA loading Dye and $5 \lambda$ PCR product was loaded in the gel. Electrophoresis was performed in voltage from 120 to $90 \mathrm{v}$.

\section{Statistical analysis}

SPSS v19 (SPSS Inc. Released 2009. PASW Statistics for Windows, Version 18.0. Chicago: SPSS Inc.) was used to analyses the data. The frequency of genes is reported as a percentage frequency. 
The results of biochemical tests showed that 20 out of 40 samples were positive for Staphylococcus aureus. The results of the PCR tests showed that all 20 positive samples had nuc nuclease gene and 6 $(30 \%)$ of 20 Staphylococcus aureus positive samples had sea genes. Figure 1 shows the results of PCR products electrophoresis.

\section{Discussion}

Because of the significance of Staphylococcus aureus strains in nosocomial infections and the role of enterotoxins as superantigens in various diseases, in the present study we evaluated the sea and nuc genes that encoding enterotoxin in Staphylococcus aureus isolates, isolated from Nasal mucosa of staff in Sari burn hospital by PCR method. According to the results, all 20 positive samples had nuc nuclease gene, and $6(30 \%)$ of 20 Staphylococcus aureus positive samples had sea gene.

In a study by Asgarpoor et al. among the 136 nasal swab samples, 46 (33.8\%) were positive for S. aureus, and from 46 isolates, the sea, seb and sec genes were found in 11 (23.9\%), 6 (13\%) and 5 (10.8\%) isolates, respectively [9]. In Rall et al. study 82 nasal and hand swabs were evaluated in food handlers and found that the most common gene was sea (35.4\%), followed by seh and sej (29.2\%) [10]. Amini et al. evaluated the Staphylococcus aureus enterotoxin genes using multiplex PCR in 60 clinical samples and showed that $50 \%$ of Staphylococcus aureus samples contained the enterotoxin gene. The most frequent gene was sea (30\%) and sed (10\%), see (3.8\%), and sec respectively [11]. In da Silva et al work, out of 58 Staphylococcus spp. 29 (50\%) were positive for one or more enterotoxin genes, and the main genes were seg and sei (29.3\%) [12]. In a study by Udo et al. in Kuwait, samples of nasal swabs, feces, and hands of 250 restaurant employees were evaluated to detect staphylococcal enterotoxin genes. From 200 isolates of Staphylococcus aureus isolated from people working in restaurants, the frequency of sea, seb, and sec genes were reported to be $11 \%, 12.5 \%$, and $23 \%$, respectively [13]. Peck et al. study in Korea showed that sea gene was the most abundant among enterotoxin genes and out of 95 strains of Staphylococcus aureus isolated from the nose of individuals, $47.4 \%$ carried this gene [14]. In the study of Saadati et al., from 95 strains of Staphylococcus aureus isolated from the noses of carriers, the frequency of sea, seb, and sec genes were $25.3 \%, 15.8 \%$, and $9.5 \%$, respectively [15].

Due to differences in sample size, geographical location, the race of individuals, and level of personal and general health, the frequency pattern of Staphylococcus aureus vectors are different. It seems that Staphylococcus aureus strains isolated in the above studies have different enterotoxinizing power and this important issue is also effective in increasing or decreasing the pathogenicity of this bacterium. It can be said that the location of bacterial colonization can affect the frequency of enterotoxigenic Staphylococcus aureus.

\section{Conclusion}

Due to the importance of pathogenicity of Staphylococcus bacteria and its role in nosocomial infections in this study, it was found that hospital staff can be considered as a source for the spread of infection in 
the hospital. The identification of enterotoxin A itself acknowledges the important role of these toxins in the development of secondary infections in patients. The high prevalence of the gene encoding this toxin, as well as the expression of this gene in isolates studied in hospitals, can be a warning and a serious threat to public health. Therefore, using the PCR method, the foci of danger can be identified quickly and possible poisoning can be prevented. Controlling the spread of such microorganisms is very important. It is very necessary for the health care system of any society to correctly identify the important and common pathogens of the hospital. Regional studies aimed at obtaining information about the species and type of Staphylococcus as well as their resistance can provide physicians with the right solutions in choosing the appropriate treatment guidelines.

\section{Limitation}

It is better the data collected from other hospitals and other cities as well. Other Staphylococcus aureus genes should be evaluated as well. Various physicochemical factors that affect the growth and production of Staphylococcus aureus toxin have been extensively studied. However, the effect of these physicochemical factors on the genes responsible for the pathogenicity of this bacterium should be studied.

\section{Abbreviations}

PCR: polymerase chain reaction

nuc gene: nuclease gene

ELISA: enzyme-linked immunosorbent assay

\section{Declarations}

\section{Acknowledgments}

The authors would like to thank the Sari Burn Hospital staff for participation in the study.

\section{Funding}

There is no funding for the present of the study.

\section{Competing interest}

There is no conflict of interest for the present study.

\section{Availability of data and materials}

The datasets used during the current study are available from the corresponding author on request. 


\section{Ethics approval and consent to participate}

The study is performed according to Helsinki principals of ethics. The ethics committee of Islamic Azad University, Ayatollah Amoli Branch approved the study. All participants signed a written consent.

\section{Authors' Contribution}

RKG and RK designed the study. Samples were collected by RK. Experiments were done by RKG and RK. Statistical analysis was done by RKG. RK wrote the first draft. RKG revised the article. Both authors read and approved the study.

\section{Consent for publication}

Not applicable.

\section{References}

1. Lowy FD. Staphylococcus aureus infections. N Engl J Med. 1998;339(8):520-32.

2. Conde A. Staphylococcus aureus infections. N Engl J Med. 1998;339(27):2026. author reply - 7.

3. Tacconelli E, Tumbarello M, Cauda R. Staphylococcus aureus infections. N Engl J Med. 1998;339(27):2026-7.

4. Pinchuk IV, Beswick EJ, Reyes VE. Staphylococcal enterotoxins. Toxins (Basel). 2010;2(8):2177-97.

5. Brakstad OG, Aasbakk K, Maeland JA. Detection of Staphylococcus aureus by polymerase chain reaction amplification of the nuc gene. J Clin Microbiol. 1992;30(7):1654-60.

6. Hawryluk T, Hirshifield I. A superanti-gen bioassay to detect staphylococcus enterotoxin A. J Food prot. 2002;65(7):1183-7.

7. Johnson WM, Tyler SD, Ewan EP, Ashton FE, Pollard DR, Rozee KR. Detection of genes for enterotoxins, exfoliative toxins, and toxic shock syndrome toxin 1 in Staphylococcus aureus by the polymerase chain reaction. J Clin Microbiol. 1991;29(3):426-30.

8. Poorabbas B, Mardaneh J, Rezaei Z, Kalani M, Pouladfar G, Alami MH, et al. Nosocomial Infections: Multicenter surveillance of antimicrobial resistance profile of Staphylococcus aureus and Gram negative rods isolated from blood and other sterile body fluids in Iran. Iran J Microbiol. 2015;7(3):127-35.

9. Asgarpoor D, Bahrami M, Daneshamooz S, Ghasemi M. Identification of Staphylococcus aureus Enterotoxin Genes of sea, seb and sec among Healthy Carriers in Ardabil City. Iranian Journal of Medical Microbiology. 2018;11(6):149-57.

10. Rall VL, Sforcin JM, Augustini VC, Watanabe MT, Fernandes A Jr, Rall R, et al. Detection of enterotoxin genes of Staphylococcus SP isolated from nasal cavities and hands of food handlers. Braz J Microbiol. 2010;41(1):59-65. 
11. Valizadeh E, Amini K. Identification of Staphylococcus Aureus Enterotoxin Genes Using Multiplex PCR. Journal of Babol University of Medical Sciences. 2016;18(12):26-32.

12. da Silva Sdos S, Cidral TA, Soares MJ, de Melo MC. Enterotoxin-Encoding Genes in Staphylococcus spp. from Food Handlers in a University Restaurant. Foodborne Pathog Dis. 2015;12(11):921-5.

13. Udo EE, Al-Mufti S, Albert MJ. The prevalence of antimicrobial resistance and carriage of virulence genes in Staphylococcus aureus isolated from food handlers in Kuwait City restaurants. BMC Res Notes. 2009;2:108.

14. Peck KR, Baek JY, Song JH, Ko KS. Comparison of genotypes and enterotoxin genes between Staphylococcus aureus isolates from blood and nasal colonizers in a Korean hospital. J Korean Med Sci. 2009;24(4):585-91.

15. Saadati M, Barati B, Doroudian M, Shirzad H, Hashemi M, Hosseini S, et al. Detection of SEA, SEB, SEC, SEQ genes in Staphylococcus aureus isolated from nasal carriers in tehran province, iran, by MULTIPLEX PCR. J Paramed Sci. 2011;2(2):34-40.

\section{Figures}




\section{\begin{tabular}{|lllllll|}
\hline 7 & 6 & 5 & 4 & 3 & 2 & 1 \\
\hline
\end{tabular}}
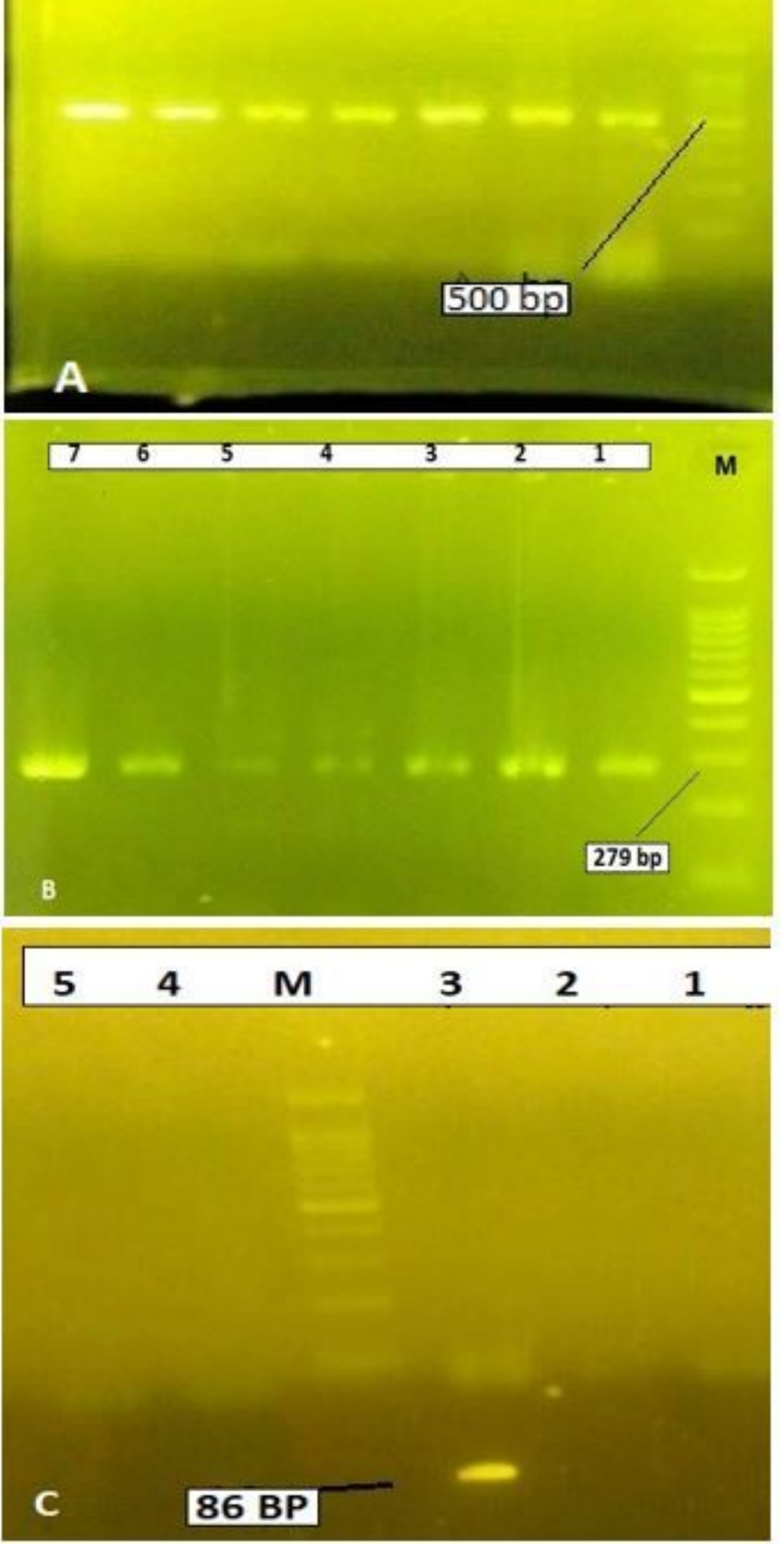

Figure 1

Electrophoresis of PCR products. A) all samples (1-7) were positive for Staphylococcus aureus, M: Marker; B) All samples were positive for nuc gene; C) Sample 3 were positive for sea gene 